DRAGAN CVETKOVIĆ, viši kustos

Muzej žrtava genocida

Beograd, Trg Nikole Pašića 11/ III

UDK 94:341.485(=411.16)(497.5)"1941/1944"(083.81)

314.117-058.65(497.1)"1941/1944"(083.81)

\title{
HOLOKAUST U NEZAVISNOJ DRŽAVI HRVATSKOJ - NUMERIČKO ODREĐENJE
}

\begin{abstract}
APSTRAKT: Rad predstavlja pokušaj da se na osnovu delimično revidiranog popisa „Žrtve rata 1941-1945“ iz 1964. godine prikaže stradanje Jevreja sa teritorije NDH. Na osnovu dostignutih rezultata u reviziji popisa, prateći do sada iskazan trend u obrađenim podacima, napravljen je proračun broja stradalih Jevreja u holokaustu (29.000-31.000). Sačinjen je pregled $u$ kome je analizirana teritorijalna pripadnost stradalih, godina i kategorija stradanja, polna struktura, odgovornost za stradanje (počinioci zločina), navedeno je nekoliko stratišta sa najvećim brojem stradalih, prikazana profesionalna struktura stradalih, te je sve smešteno $u$ kontekst opšteg stradanja u NDH i Jugoslaviji.
\end{abstract}

Ključne reči: Holokaust, NDH, Jevreji, Hrvatska, Bosna i Hercegovina, Srem, stradanje, ustaše, Nemci, koncentracioni logori, Jasenovac

Holokaust, kao najekstremniji oblik do sada poznatog genocida i prva pojava nekih vrsta zločinačkih ubistava i zločinačkog mišljenja, ${ }^{1}$ imao je na prostoru podeljene Jugoslavije niz specifičnosti u „rešavanju jevrejskog pitanja“, kao ni u jednom drugom delu Evrope, ali se time nikako ne izdvaja iz opšteg konteksta stradanja Jevreja. Njihovo stradanje u Nezavisnoj Državi Hrvatskoj (NDH) svakako predstavlja jedan od vidova te specifičnosti. Uz uvažavanje rezultata dosadašnjih istraživanja holokausta, ${ }^{2}$ ovaj članak ima cilj da preciznije odredi broj u holokaustu stradalih Jevreja NDH na osnovu poimeničnog popisa. ${ }^{3}$

${ }^{1}$ Yehuda Bauer, Is the Holocaust explicable, Израелско-српска научна размена $у$ проучаваьу холокауста /Israeli-Serbian academic exchange in Holocaust research, ur. Jovan Mirković, Beograd 2008, 149.

${ }^{2} \mathrm{Za}$ kraći pregled značajnijih radova u istraživanju holokausta do 2006. godine videti: Milan Koljanin, Istraživanje holokausta u Jugoslaviji, u: Izraelsko-srpska naučna razmena..., 264-273.

${ }^{3}$ Značajniji radovi sa poimeničnim popisima stradalih Jevreja: Melita Švob, Židovi u Hrvatskoj - židovske zajednice, Zagreb 2004, 7-644; Samjuel Pinto, Zločini okupatora i njihovih pomagača izvršeni nad Jevrejima Bosne i Hercegovine, Sarajevo 1952, 4-661; Mladenko Kumović, 
Jugoslavija se po završetku rata, kao i sve druge zemlje učesnice, susrela sa problemom utvrđivanja ratnih gubitaka koji se mogao rešiti demografskim proračunom ili popisivanjem stradalih. Posle prve posleratne procene od 1.706.000 stradalih osoba, ${ }^{4}$ pojavilo se kasnije još nekoliko procena (u zemlji i inostranstvu) kako demografskih gubitaka, tako i stvarnih ratnih gubitaka Jugoslavije. ${ }^{5}$ Takođe, postoji nekoliko procena o broju stradalih Jevreja koje se razlikuju u zavisnosti od metodologije kojom su se služili istraživači. Procene demografa pokazuju da je stradalo 57.000 odnosno $60.000 \mathrm{Jevreja}^{6}{ }^{\mathrm{d}}$ dok je procena istraživača koji su se bavili analizom dokumenata pokazala da se broj stradalih kreće između 56.000 i 67.000 . $^{7}$

Posle nekoliko neuspelih pokušaja popisivanja stradalih, ${ }^{8}$ država je 1964. godine pokušala da izvrši popis na celoj svojoj teritoriji, ali se zbog ideološke op-

Страдағе сремских Јевреја у холокауст у /The persecution of the Jews from Srem during the Holocaust, Novi Sad 2007, 7-253.

${ }^{4}$ Arhiv Jugoslavije, Beograd (dalje AJ), 54-1-3 Reparaciona komisija pri vladi FNRJ.

${ }^{5}$ Demografski gubitak su procenili: Prinstonski univerzitet na 1.200.000 (1944. godine), D. Tasić 2.428.000 (1951), D. Vogelnik 2.850. 000 do 3.250.000 (1952), I. Lah 2.100.000 (1952), G. Ipsen 1.690.000 (1954), B. Kočović 1.985 .000 (1985), V. Žerjavić 2.022.000 (1989), R. Petrović 2.693 .000 (1991) Ž. Đorđević 2.825 .000 (1997), dok su stvaran ratni gubitak procenili Tasić na 1.400.000, Vogelnik na 1.800.000, Lah na 1.000.000, G. Frumkin na 1.500.000 (1961), Komisija za popis „Žrtve rata $1941-1945^{\prime \prime}(1964)$ na 1.016 .000 do 1.066 .000 odnosno na 1.106 .000 i 1.156 .000 , Kočović 1.014.000, Žerjavić 1.027.000, R. Petrović 1.560.693, Đorđević 1.838.000. Drastične razlike koje se javljaju (od 2.050.000 kod demografskih i 838.000 kod stvarnih gubitaka) posledica su različitih metodoloških pristupa, posebno u određivanju stope godišnjih priraštaja, broja stanovnika novopriključenih oblasti i broja emigriralih stanovnika. (Opširnije u Jovan Mirković, Objavljeni izvori i literatura o jasenovačkim logorima, Banja Luka-Beograd 2000, 212-222).

${ }^{6}$ Vladimir Žerjavić, Gubici stanovništva Jugoslavije u Drugom svjetskom ratu, Zagreb 1989, 75 (oko 57.000); Bogoljub Kočović, Žrtve Drugog svetskog rata u Jugoslaviji, London 1985, $182(60.000)$.

${ }^{7}$ Zločini fašističkih okupatora i njihovih pomagača protiv Jevreja Jugoslavije, ur. Zdenko Levntal, Beograd 1952, XIX, (60.000); Jaša Romano, Jevreji Jugoslavije 1941-1945 žrtve genocida i učesnici narodnooslobodilačkog rata, Beograd 1980, 14 (65.500 stradalih u holokaustu i 1.300 stradalih u pokretu otpora); Milan Ristović, U potrazi za utočištem, jugoslovenski Jevreji u bekstvu od holokausta 1941-1945, Beograd 1998, 337 (oko 60.000); Encyclopedia of the Holocaust, ur. Robert Rozett Shmuel Spektor, Yad Vashem, Jerusalim 2000, 490 (oko 66.000); Historical atlas of the Holocaust, ur. Yechiam Halevy, USHMM Vašington 1996, 175 (oko 60.000); Robert Vistrič, Hitler i Holokaust, Beograd 2004, 8 (56.200).

${ }^{8}$ Prvi pokušaj popisivanja ratnih žrtava sprovela je Državna komisija za utvrđivanje zločina okupatora i njihovih pomagača 1946. godine, ali popis nije bio uspešan usled propusta u radu i nesaradnje među zemaljskim komisijama, tako da je obuhvatio samo 505.182 osobe što je smatrano nedovoljnim, pa je trebalo da bude ponovljen, ali to nije učinjeno. (Miodrag Zečević, Jovan Popović, Dokumenti iz istorije Jugoslavije, Državna komisija za utvrđivanje zločina okupatora i njihovih pomagača iz drugog svetskog rata, Beograd 1996, knj. I, 42). SUBNOR je radio popise po opštinama 1950. godine (pojedinačni podaci nisu nikada objavljeni, postoje zbirni podaci za Hrvatsku), zatim popise preživelih pripadnika NOB-a i učestvovao je sa drugim istraživačima u izradi i objavljivanju lokalnih monografija sa popisima palih boraca i ,žrtava fašističkog terora“. Crveni krst je takođe prikupljao podatke o stradalima. Jevrejske opštine su prikupljale podatke za sunarodnike stradale $u$ holokaustu. 
terećenosti sa realizacijom krenulo iz pogrešnih osnova, a i sama metodologija izrade popisa bila je manjkava. ${ }^{9}$ Popisano je 597.323 osoba, ${ }^{10}$ ali je popisna komisija utvrdila da je učinjen niz propusta pri izradi popisnika tako da je njime obuhvaćeno 56-59\% lica od onih koje je trebalo obuhvatiti popisom. ${ }^{11}$ Pošto je popisnik prvenstveno sačinjen radi naplate ratne štete od Nemačke, dobijeni broj stradalih u ratu bio je daleko od očekivanog i do tada važećeg broja 1.706.000 tako da je odlučeno da se stavi embargo na njegovo korišćenje. Zabrana je trajala do 1992. godine, a gubitak vremena je smanjio mogućnost utvrđivanja pravog broja stradalih, zbog biološkog nestanka svedoka, čime je znatno otežana njegova revizija. ${ }^{12}$ Popisom Žrtve rata $1941-1945$ iz 1964. godine identifikovano je 45.000 stradalih Jevreja. U dosadašnjem procesu revizije broj stradalih Jevreja je utvrđen na 52.577 što je uvećanje od 16,84\% (7.577 osoba). U odnosu na ukupan broj stradalih Jevreja iz Jugoslavije (oko 60.000) broj identifikovanih predstavlja oko $88 \%,{ }^{13}$ što je iznad prosečne uspešnosti revizije kojom je obuhvaćeno izme-

${ }^{9}$ U Saveznom izvršnom veću je 11. maja 1964. održan sastanak na kome su „doneti sledeći zaključci: 1. Da se izvrši opšti popis svih žrtava rata. Ovo pogotovo što za sada ne postoji takva konkretna dokumentacija koja bi mogla da posluži za podnošenje odštetnog zahteva prema Nemačkoj ni u jednoj republici. Lica koja su poginula u kvislinškim organizacijama ne bi se obuhvatala popisom... (up. Igor Graovac, Dragan Cvetković, Ljudski gubici Hrvatske 1941-1945. godine: pitanja, primjeri, rezultati..., Zagreb 2005, 53; opširnije o pregovorima: Zoran Janjetović, Od Auschwitza do Brijuna, Pitanje odštete žrtava nacizma u jugoslovensko-zapadnonjemačkim odnosi$m a$, Zagreb 2007).

${ }^{10}$ Odbijanjem broja stradalih sa teritorija priključenih Jugoslaviji posle 1945. godine dobija se broj stradalih sa teritorije Kraljevine Jugoslavije koji iznosi 580.981.

${ }_{11}$ Žrtve rata 1941-1945 (rezultati popisa), Savezni zavod za statistiku (SZS), Beograd 1966, 5-22. - Popisna komisija je proračunala da bi popisom trebalo obuhvatiti 1.016.000 do 1.066.000 osoba. Procena je izvršena u Saveznom zavodu za statistiku uz stručnu saradnju dr Dušana Breznika, upravnika Centra za demografska istraživanja. Pošto u broj koji je trebalo obuhvatiti popisom nije uračunato procenjenih oko 50.000 stradalih kvislinga kao ni oko pretpostavljenih 40.000 Roma i Jevreja za koje nije imao ko da pruži podatke, proizlazi da je u Jugoslaviji u ratu stradalo između 1.106.000 i 1.156 .000 osoba, što znači da je popisom obuhvaćeno između 51,7 i $54 \%$ stvarno stradalih iz Jugoslavije. Novija demografska istraživanja i analiza ovog popisa upućuju na to da za polaznu tačku u istraživanjima treba uzeti procenu o broju stradalih koja se kreće između 1.070 .000 i 1.120 .000 osoba, odakle sledi da je popisom obuhvaćeno između 53,3-55,8\% stradalih. Procenjen broj za teritoriju KJ iznosi između 1.042 .000 i 1.092 .000 stradalih.

${ }^{12}$ Muzej žrtava genocida je počeo reviziju sa idejom da se obuhvate sva lica koja su živela na prostoru Jugoslavije bez obzira na nacionalnu, versku, etničku, političku i vojnu pripadnost čime se ispravlja osnovna metodološka greška nepopisivanja „,kolaboracionista“. Ispravka je usmerena i na utvrđivanje počinilaca zločina odnosno odgovornih za stradanje što nije činjeno 1964. godine, na utvrđivanje broja Roma koji nisu posebno popisivani već su vođeni uglavnom kao ostale ili nepoznate nacionalnosti ili pak kao Hrvati, a u manjem broju kao Srbi ili Muslimani, zatim na otklanjanje netačnosti u podacima, što sve dovodi do promenjivosti podataka. Stoga izložene podatke vezane za ove kategorije treba primiti sa rezervom. Do sada je revizijom za područje Jugoslavije utvrđen broj od 657.290 stradalih što je povećanje od 10,04\% (59.967 osoba). (AJ, Fond 179, popis Žrtve rata 1941-1945; Arhiv Muzeja žrtava genocida (dalje AMŽG), fond Žrtve rata 1941-1945. godine).

${ }^{13}$ Za procenu je uzet broj od 60.000 stradalih Jevreja. Ako uzmemo u razmatranje ekstremne vrednosti od 57.000 odnosno 67.000 stradalih, tada broj identifikovanih (52.577) predstavlja oko 92 odnosno $78 \%$. 
đu 58,69 i 61,43\% stradalih stanovnika Jugoslavije. Nerealna je pomisao da će revizija obuhvatiti sve nepopisane žrtve, ali će se, svakako, utvrđen broj stradalih približiti stvarnom broju stradalih, čime bi se smanjio prostor za manipulacije, a ujedno i odala pošta žrtvama njihovim izuzimanjem od zaborava.

Pored glavnog pitanja koliko je stradalih, značajno pitanje za istraživače jeste šta pokazuju rezultati popisa, odnosno kakva je unutrašnja struktura stradalih. Iako nepotpun, popis je po podacima sa kojima raspolaže vrlo indikativan, jer pruža mogućnost analize na vrlo reprezentativnom uzorku od oko $88 \%$ stradalih Jevreja. Dosadašnje iskustvo u prezentiranju dostignutih rezultata revizije popisa pokazuje da su oni uglavnom pogrešno (ili možda namerno) smatrani konačnim, te su kao takvi predstavljani u medijima i istoriografskoj literaturi. Na osnovu dostignutih rezultata u reviziji popisa, a prateći do sada iskazan trend u kretanju dobijenih podataka, napravljena je procena broja stradalih, te su sve analize urađene na osnovu proračunatog broja stradalih. Težište u radu je analiza podataka delimično revidiranog popisa „Žrtve rata 1941-1945“ koji se odnosi na u holokaustu stradale Jevreje. Podaci o stradanjima ostalih nacionalnih grupa sa teritorije NDH priloženi su radi poređenja sa stradanjem Jevreja, čime je olakšano sagledavanje razmera njihovog stradanja, uz uvažavanje razlike koja postoji između holokausta i ostalog stradanja u ratu, ma koliko ona bila velika. Napravljen je kratak pregled u kome su analizirane teritorijalna pripadnost stradalih Jevreja, godine i okolnosti stradanja, polna struktura, počinioci zločina, odnosno odgovorni za njihovo stradanje, navedeno je nekoliko stratišta sa najvećim brojem stradalih, prikazana profesionalna struktura stradalih, te je sve smešteno u kontekst opšteg stradanja stanovništva u NDH.

Pre pregleda stradanja potrebno je utvrditi broj Jevreja koji su živeli u Jugoslaviji. U rešavanju ovog problema ponovo dolazimo do različitih podataka kod demografa i ostalih istraživača. Demografi su utvrdili da je u Jugoslaviji živelo 73.000 Jevreja što je bilo $0,46 \%$ ukupnog stanovništva. Ovde svakako nisu uračunati emigranti koji su se zatekli na teritoriji Jugoslavije, a kojih je bilo između 3.000 i 5.000. Brojnost jevrejske populacije kod istraživača koji su se bavili dokumentima procenjena je između 71.000 i $82.000 .{ }^{14}$ Procenjen broj Jevreja koji su preživeli rat kreće se od 8.000 do $16.000 .{ }^{15}$

Izdvajanje teritorije koju je činila NDH pokazuje da je broj nastanjenih Jevreja na njoj, takođe, procenjivan različito i on se kreće od 34.000 do 40.000

${ }^{14}$ Zločini fašističkih okupatora $i$ njihovih pomagača protiv Jevreja Jugoslavije, XIX (75.000 početkom rata, bez navođenja da li su u ovaj broj uračunati i emigranti); Albert VAJS, Spomenica, Beograd 1965, 127 (oko 71.000); J. Romano, Jevreji..., 14 (82.242); Encyclopedia..., 489 (oko 80.000); Historical atlas..., 14 (oko 70.000 u predratnom periodu), 171 (oko 80.000 u vreme okupacije).

${ }^{15}$ Zločini fašističkih okupatora i njihovih pomagača protiv Jevreja Jugoslavije, XIX (15.000); J. Romano, Jevreji..., 14 (oko 15.000); M. Ristović, U potrazi..., 337 (8.000 do 10.000); B. Kočović, Žrtve..., 164 i 182 (oko 13.000); V. Žerjavić, Gubici..., 36-46 (oko 16.000); Mladenka Ivanković, Jevreji u Jugoslaviji (1944-1952) Kraj ili novi početak, Beograd 2009, 353 (12.495 u Jugoslaviji 27. novembra 1946). 
tako da su predstavljali $0,54 \%$ do $0,64 \%$ populacije. ${ }^{16}$ U ovaj broj nisu uračunati imigranti koji su se tu zatekli posle formiranja NDH. Od ostalih nacionalnosti bilo je, prema izvoru iz nemačkog Ministarstva spoljnih poslova, među 6.285 .000 stanovnika (bez navođenja broja Roma ${ }^{17}$ ) 52,51\% Hrvata (3.300.000), 30,63\% Srba (1.925.000), 11,14\% Muslimana (700.000), 2,39\% Nemaca (150.000), 1,19\% Mađara (75.000), 0,48\% Slovenaca (30.000) i 1,03\% Čeha i Slovaka (65.000). ${ }^{18}$ Broj stradalih Jevreja iz NDH je različito procenjivan tako da se u literaturi nalaze podaci koji se kreću od 27.000 do preko $31.000{ }^{19}$ Do sada nije pouzano utvrđen broj stradalih emigranata u NDH, što je otežano činjenicom da nije poznat ni njihov broj koji se zatekao na ovoj teritoriji početkom rata. ${ }^{20}$ Procenjen broj preživelih se kreće između 4.700 i $9.000 .{ }^{21} \mathrm{Na}$ teritoriji NDH Jevreji nisu bili ravnomerno nastanjeni, tako da ih je 61,97\% živelo na teritoriji Hrvatske, $33,80 \%$ na teritoriji BiH i 4,23\% na teritoriji Srema. ${ }^{22}$ Najveće jevrejske zajedni-

${ }^{16}$ B. Kočović, Žrtve..., 173-176 (36.000); V. Žerjavić, Gubici.., 36-45 (36.000), različito u Demografski pokazatelji o stradanju Židova u NDH, u: Antisemitizam - Holokaust - Antifašizam, Zbornik radova, ur. Ognjen Kraus, Zagreb 1996, 136 (34.400); Encyclopedia..., 175 (37.000); Ivo Goldstein, Holocaust u Zagrebu, Zagreb 2001, 17, 636 (38.000-39.000); J. Romano, Jevreji..., 133 (39.500); R. Vistrič, Hitler..., 146 (38.000). Realno je broj Jevreja u NDH bio nešto manji pošto je manji deo njih, odmah po njenom formiranju, napustio ovu teritoriju.

${ }^{17}$ Kao osnova za proračune u daljem radu uzet je aproksimativan broj od 30.000 Roma u NDH. Demografska istraživanja na osnovu popisa jezičke pripadnosti pokazala su da je na toj teritoriji živelo oko 21.000 Roma, mada je svakako postojao deo koji se nije izjasnio ili je pak bio dovoljno asimilovan da je govorio drugim jezikom (većim delom hrvatskim i manjim srpskim, što otvara pitanje njihovog nacionalnog identiteta), te su se i ne retko tako i nacionalno opredeljivali. (B. Kočović, Žrtve...., 173-176; V. Žerjavić, Gubici..., 36-45). Dosadašnji rezultati u broju identifikovanih Roma tokom revizije popisa, aktuelna obuhvaćenost potencijalnih žrtava, iskazan trend u pristizanju podataka i naročito nesrazmerno veliki udeo dece do 14 godina među identifikovanima, pokazuju da je ukupan broj stradalih Roma veći od broja koji su demografi procenili kao ukupan broj Roma ove teritorije.

${ }^{18}$ Prema ovoj proceni na teritoriji NDH je živelo oko 40.000 Jevreja. (Fikreta Jelić-Butić, Ustaše i NDH, Zagreb 1977, 106.) Pošto je za Kraljevinu Jugoslaviju procenjeno da je 1941. godine imala 15.831 .000 stanovnika (B. Kočović, Žrtve..., 164), odnosno 15.973 .000 stanovnika (V. Žerjavić, Gubici..., 80) sledi da je na teritoriji NDH živelo 39,35 do $39,70 \%$ njenih stanovnika.

${ }^{19}$ V. Žerjavić, Gubici..., 75, (oko 27.500), Demografski pokazatelji..., 137, (26.900); B. Kočović, Žrtve..., 173-176 (oko 28.500); Encyclopedia..., 175, (oko 30.000); I. Goldstein, Holokaust..., 17, 636, (30.000 do 31.000); J. Romano, Jevreji..., 133 (30.500); R. Vistrič, Hitler..., 146 (upoređujući sa stradanjem Jevreja u Srbiji, autor navodi da je ,ista sudbina“ zadesila i 38.000 Jevreja NDH, ne iznoseći preciznije podatke o broju stradalih ili preživelih).

${ }^{20}$ Prema J. Romanu u NDH je stradao najmanje 1.571 emigrant iz Nemačke, Austrije, Poljske i Čehoslovačke i to 865 zatečenih na teritoriji Hrvatske (iz Zagreba, Daruvara i Suška po 200, Draganića 178, Lipika 59, Pisarovine 28 itd.), 506 BiH (iz Brčka i Čapljine po 147, Dervente 120, Slatine kod Banja Luke 58, Bosanskog Šamca 34 itd.) i 200 na teritoriji Srema (Ruma). (J. Romano, Jevreji..., 133)

${ }^{21}$ Encyclopedia..., 175, (oko 7.000); B. Kočović, Žrtve..., 173-176 (oko 7.000); V Žerjavić, Gubici..., 36-45, 75, (oko 8.000), u „Demografski pokazatelji...“, 136, (4.700); J. Romano, Jevreji..., 133 (9.000); I. Goldstein, Holokaust..., 636 (9.000).

${ }^{22}$ Demografi su procenili da je u Hrvatsko j živelo 22.000 i u BiH 12.000 Jevreja. (V. Žerjavić, Gubici...., 36,39; B. Kočović, Žrtve...., 173-174) Procena je da je u Sremu živelo oko 1.500 Jevreja. 
ce su živele u Zagrebu i neposrednoj okolini, oko $12.000{ }^{23}$ Sarajevu око $10.500^{24}$ i Osijeku oko $2.500,{ }^{25}$ dok su manje zajednice živele u ostalim većim gradovima ili manjim mestima u blizini velikih gradova naročito u Sremu, Slavoniji i severozapadnoj Hrvatskoj.

Dezintegracijom i podelom Kraljevine Jugoslavije koju su sproveli pobednici potvrđeno je postojanje NDH, s time što su Nemačka i Italija odredile svoje zone uticaja i zadržale određene vojne efektive u njima. Odmah po formiranju države i uspostavljanju vlasti, sledeći načela i politički program koji su do tada zastupali, koristeći pogodnu antisemitsku atmosferu u Banovini Hrvatskoj, ${ }^{26}$ ustaše su objavile niz zakona koji su bili upereni protiv Jevreja, Roma i Srba, pravno ozakonjujući diskriminaciju i teror koji su sprovodili nad njima. Holokaust je najavljen donošenjem niza rasnih zakona koji su bili upereni protiv Jevreja, ali i Roma. ${ }^{27} \mathrm{U}$ periodu od prva dva meseca postojanja vlasti NDH su donele 15 zakonskih odredbi koje su bitno uticale na društveni i ekonomski položaj Jevreja, a zatim i na njihov opstanak na ovom prostoru. ${ }^{28}$ Srbi su, kao glavni protivnik u novoformiranoj državi, bili pod udarom antidržavnih zakona, od kojih su pojedini korišćeni i protiv Jevreja. ${ }^{29}$

Za polaznu tačku u istraživanju uzet je broj stradalih Jugoslavije koji je proizašao iz procesa nastanka popisa Žrtve rata 1941-1945, a koji se kreće izme-

${ }^{23}$ I. Goldstein, Holokaust..., 26.

${ }^{24}$ S. Pinto, Zločini okupatora..., 61.

${ }^{25}$ M. Švob, Židovi u Hrvatskoj..., 369.

${ }^{26}$ Opširnije o antisemitizmu na teritoriji Banovine Hrvatske i sprovođenju antijevrejskih zakona: M. Koljanin, Jevreji i antisemitizam u Kraljevini Jugoslaviji, Beograd 2008, 284-315 i 436-444.

${ }^{27} \mathrm{O}$ rasnom zakonodavstvu opširnije u: Zločini na jugoslovenskim prostorima u prvom $i$ drugom svetskom ratu - zbornik dokumenata, ur. Slavko Vukčević, Beograd 1993, 22-28, 48-49, 73-77, 81-86.; Ustaša, dokumenti o ustaškom pokretu, ur. Petar Požar, Zagreb 1995, 149, 165-169, 171,173,201-203, 348; O sprovođenju rasnog zakonodavstva i njegovom uticaju na jevrejsku zajednicu opširnije u: I. Goldstein, Holokaust..., 117-198, 223-233.

${ }^{28}$ U obzir su uzete samo one odredbe koje su imale odlučujući uticaj na sudbinu jevrejske zajednice, a za čije neizvršavanje je bila zaprećena smrtna kazna ili dugogodišnja robija. Pored njih, doneto je još dosta propisa koji su se ticali života Jevreja u pojedinim područjima. Među važnijim zakonskim odredbama izdvaja se vanredna zakonska odredba i zapovest Poglavnika, od 26. juna 1941, o nadležnosti prekih sudova sa posebnim naglaskom o postupku prema Jevrejima. Prema njoj se zbog širenja lažnih vesti (o ustanku - D. C.) i bavljenja trgovinskim špekulacijama, a koje otežavaju snabdevanje stanovništva, Jevreji smatraju kolektivno odgovornim, pa se, kao takvi, imaju uputiti u sabirne logore pod vedrim nebom. (Zločini..., 154-155). U periodu objavljivanja ove odredbe, pored više manjih sabirnih logora, već je bila oformljena gospićka grupa logora (Gospić, Jadovno, Pag) kao prvi veliki logorski sistem NDH i prvo veliko stratište, prvenstveno, za Jevreje i Srbe. (Đuro Zatezalo, Јадовно - комплекс усташких логора 1941, књига I, Beograd 2007, $105,112,126)$.

${ }^{29}$ Već 17. aprila doneta je Zakonska odredba za odbranu naroda i države, prema kojoj su svi osumnjičeni izvođeni pred preki sud koji je osuđivao isključivo na smrtnu ili oslobađajuću kaznu. (Zločini..., 16); Zakonska odredba poglavnika od 25. novembra o upućivanju „nepoćudnih i pogibeljnih" osoba na prisilni boravak u sabirne i radne logore. Odluku o upućivanju u logore donosi ustaško redarstvo i protiv nje nema žalbe (Isto, 851-852). 
đu 1.070.000 i 1.120.000 osoba, odnosno između 1.042 .000 i 1.092 .000 za teritoriju Kraljevine Jugoslavije (KJ). ${ }^{30}$ Proračunom za teritoriju koja je približno jednaka teritoriji NDH dolazimo do broja koji se kreće između 690.000 i 736.000 stradalih. Stradali iz NDH predstavljaju $66,82 \%$ ljudskih gubitaka Jugoslavije, što je veliko stradanje s obzirom na učešće od $39,35 \%$ u njenoj populaciji. Odnos u broju stradalih stanovnika NDH prema ostalom delu Jugoslavije iznosi 2,01:1. Razvrstavanje po kategorijama pokazuje da je u NDH život izgubilo između 499.000 i 530.000 civila. ${ }^{31}$ Gubici civilnog stanovništva predstavljaju $72,16 \%$ ukupnih ljudskih gubitaka NDH, a ujedno civili iz NDH čine 73,36\% stradalih civila Jugoslavije. ${ }^{32}$ Poređenja radi, u ostalom delu Jugoslavije, dakle van teritorije $\mathrm{NDH}$, učešće civila među stradalima je $52,68 \%{ }^{33}$ Analiza nacionalne strukture stradalih civila pokazuje da je među njima 332.000 do 352.000 Srba ili $66,47 \%$, 51.000 do 54.000 Hrvata što je 10,20\%, 39.000 do 41.000 Muslimana ili 7,77\%, 29.000 do 31.000 Jevreja ili $5,83 \%, 24.000$ do 26.000 Roma ili $4,86 \%, 6.000$ do 7.000 ostalih nacionalnosti što je $1,26 \%$ i 18.000 do 19.000 neutvrđenih ${ }^{34}$ nacionalnosti ili 3,60\%.

Rasnim zakonima izopšteni iz društva, Jevreji su u holokaustu uništeni gotovo u potpunosti, tako da sa učešćem od $0,59 \%$ u stanovništvu NDH predstavljaju 5,83\% stradalih civila ove teritorije. Iako su Srbi daleko najbrojniji među stradalim civilima, a Hrvati i Muslimani kao „državotvorni“ narodi, takođe, imaju više stradalih, Jevreji i Romi su, s obzirom na učešće u populaciji, najveće žrtve u NDH. Među stradalim civilima učešće Jevreja je 10 puta veće od njihovog učešća u populaciji NDH. Upoređujući sa civilnim žrtvama tri većinska naroda, odnos u stradanju Jevreja prema Hrvatima je 1:1,75, prema Muslimanima 1:1,33 i prema Srbima je 1:11,40, ali s obzirom na njihovo učešće u stanovništvu (1:89,19 u odnosu na Hrvate, 1:18,88 na Muslimane i 1:51,92 na Srbe) stvarni odnos u stradanju iznosi 50,97:1 u odnosu na Hrvate, 13,96:1 u odnosu na Muslimane, kao i 4,55:1 u odnosu na Srbe. Upoređeni sa Romima, kao drugom manjinskom nacionalnom grupom koja je pretrpela izuzetno velika stradanja, Jevreji imaju odnos u stradanju od 1,20:1, ali s obzirom na njihovu zastupljenost u stanovništvu NDH (1,20:1), stvaran odnos u stradanju dva naroda je 1:1.

\footnotetext{
${ }^{30}$ Dalje se u radu pod pojmom Jugoslavije podrazumeva teritorija, stanovništvo i broj stradalih Kraljevine Jugoslavije.

${ }^{31}$ U NDH je stradalo 5.000-6.000 pripadnika Vojske Kraljevine Jugoslavije u Aprilskom ratu i u logorima za ratne zarobljenike $(0,75 \%$ do $0,80 \%$ stradalih), između $149.000-157.000$ pripadnika NOVJ (20,79\% do $22,17 \%$ stradalih) i između pretpostavljenih $37.000-43.000$ pripadnika ostalih vojnih formacija (5,43\% do 5,80\% stradalih).

${ }^{32}$ Procenjeni broj stradalih civila Jugoslavije se kreće između $684.000-718.000$ što je $65,70 \%$ stradalih.

${ }^{33}$ Odnos u broju stradalih civila NDH i ostatka Jugoslavije iznosi 2,76:1, ali s obzirom da je teritoriju NDH nastanjivalo 39,35\% populacije Jugoslavije taj odnos u stradanju iznosi 4,25:1.

${ }^{34}$ Preliminarne analize koje su rađene za grupu „,neutvrđene nacionalnosti“ pokazuju da je među njima najviše Srba i Roma, ali za sada ne postoje validni izvori koje potvrđuju ove pretpostavke.
} 
Stradanje u holokaustu tokom godina rata nije bilo ravnomerno. Najveći deo Jevreja NDH, 60,53\%, izgubio je život druge godine rata, a od ostalih se izdvajaju prva godina sa $19,14 \%$ i poslednja godina rata u kojoj je za četiri i po meseca stradalo 7,97\% Jevreja NDH. Najveći deo, 57,67\%, stradalih potiče iz Hrvatske, što je manje od njihovog učešća u ukupnom broju Jevreja NDH $(61,97 \%)$. Stradalih Jevreja iz BiH je $38,17 \%$, što je iznad njihovog učešća u jevrejskoj zajednici NDH $(33,80 \%)$. Iz Srema potiče 4,17\% stradalih Jevreja, što odgovara njihovom učešću u ukupnom broju Jevreja NDH (4,23\%). Međutim, ni stradanje na različitim teritorijama nije bilo jednako u pojedinim periodima rata.

\begin{tabular}{|c|c|c|c|c|c|c|c|c|c|c|c|}
\hline \begin{tabular}{|l} 
Jevreji \\
NDH
\end{tabular} & 1941 & $\%$ & 1942 & $\%$ & 1943 & $\%$ & 1944 & $\%$ & 1945 & $\%$ & Ukupno \\
\hline $\begin{array}{l}\text { Hrvat- } \\
\text { ska }\end{array}$ & $\begin{array}{l}3.504- \\
3.755 \\
\end{array}$ & 20,98 & $\begin{array}{l}8.398- \\
9.002\end{array}$ & 50,29 & $\begin{array}{l}1.212- \\
1.300\end{array}$ & 7,26 & $\begin{array}{l}1.597- \\
1.711\end{array}$ & 9,56 & $\begin{array}{l}1.989- \\
2.132\end{array}$ & 11,91 & $\begin{array}{l}16.700- \\
17.900\end{array}$ \\
\hline$\%$ & 63,21 & $/ 1$ & 47,91 & $/ /$ & 70,86 & $/ /$ & 85,37 & $/ 1$ & 86,23 & $/ 1$ & 57,67 \\
\hline$\overline{\mathrm{BiH}}$ & $\begin{array}{l}1.881- \\
2.000\end{array}$ & 16,95 & \begin{tabular}{|l|}
$8.221-$ \\
8.739
\end{tabular} & 74,06 & $\begin{array}{l}462- \\
491\end{array}$ & 4,16 & $\begin{array}{l}234- \\
249\end{array}$ & 2,11 & $\begin{array}{l}302- \\
321\end{array}$ & 2,72 & $\begin{array}{l}11.100- \\
11.800\end{array}$ \\
\hline$\%$ & 33,80 & $/ /$ & 46,70 & $/ /$ & 26,88 & $/ /$ & 12,46 & $/ /$ & 13,04 & $/ /$ & 38,17 \\
\hline Srem & $\begin{array}{l}165- \\
178 \\
\end{array}$ & 13,71 & $\begin{array}{l}940- \\
1.018\end{array}$ & 78,32 & $38-42$ & 3,19 & $40-44$ & 3,37 & $17-18$ & 1,41 & $\begin{array}{l}1.200- \\
1.300\end{array}$ \\
\hline$\%$ & 2,99 & $/ 1$ & 5,39 & $/ 1$ & 2,26 & $/ /$ & 2,17 & $/ 1$ & 0,73 & $/ 1$ & 4,17 \\
\hline Ukupno & $\begin{array}{l}5.550- \\
5.933\end{array}$ & 19,14 & \begin{tabular}{|l|}
$17.559-$ \\
18.759
\end{tabular} & 60,53 & $\begin{array}{l}1.712- \\
1.833\end{array}$ & 5,91 & $\begin{array}{l}1.871- \\
2.004\end{array}$ & 6,46 & $\begin{array}{l}2.308- \\
2.471\end{array}$ & 7,97 & $\begin{array}{l}29.000- \\
31.000\end{array}$ \\
\hline
\end{tabular}

Iako je druga godina bila najpogubnija po Jevreje NDH, primetne su razlike među različitim delovima države, tako da je tada život izgubilo 50,29\% Jevreja iz Hrvatske, 74,06\% Jevreja BiH i 78,32\% Jevreja iz Srema. U poslednje dve godine rata život je izgubilo $21,46 \%$ Jevreja iz Hrvatske, dok je u tom periodu stradalo 4,83\% Jevreja BiH i 4,78\% Jevreja iz Srema. Kao najbrojniji, Jevreji iz Hrvatske imaju stalno natpolovično učešće među stradalima, od $63,21 \%$ u prvoj do 86,23\% u poslednjoj godini rata, sa jedinim padom ispod polovine u 1942. godini, kada iznosi 47,91\%. Jevreji iz BiH najveće učešće među stradalima imaju u drugoj godini rata, kada ono iznosi $46,70 \%$ i gotovo je izjednačeno sa učešćem Jevreja iz Hrvatske. Od ostalih ratnih godina, imaju značajnije učešće u prvoj od 33,80\%. Kao najmanja zajednica Jevreji iz Srema imaju zapaženije učešće među stradalima od 5,39\% u 1942. godini. Stopa smrtnosti u drugoj godini rata, u odnosu na sedam meseci masovnog stradanja u prvoj godini, uvećana je 1,85 puta, ali ne ravnomerno u svim delovima NDH. Kod Jevreja iz Hrvatske uvećana je za 1,40 puta, u BiH za 2,55 puta, a u Sremu za 3,33 puta.

Izrazito kompleksan i brutalan rat koji je vođen na ovom području, a koji je sadržavao elemente oslobodilačkog, antifašističkog, građanskog, međunacionalnog, verskog, ideološkog rata uz sprovođenje holokausta i genocida neminovno je doveo do velikog stradanja pripadnika oba pola. Analiza polne strukture stradalih civila pokazuje da su Jevreji u NDH pretrpeli podjednako stradanje pri- 
padnika oba pola (preciznije samo oni imaju natpolovično učešće žena među stradalima), po čemu su im slični jedino Romi.

\begin{tabular}{|l|r|r|r|r|}
\hline Polna struktura & \multicolumn{1}{|c|}{ Muškarci } & \multicolumn{1}{c|}{$\%$} & \multicolumn{1}{c|}{ Žene } & \multicolumn{1}{c|}{$\%$} \\
\hline Jevreji & $13.908-14.868$ & 47,96 & $15.092-16.132$ & 52,04 \\
\hline Romi & $12.626-13.679$ & 52,61 & $11.374-12.321$ & 47,39 \\
\hline Srbi & $214.007-226.899$ & 64,46 & $117.993-125.101$ & 35,54 \\
\hline Hrvati & $37.444-38.913$ & 73,42 & $13.556-14.087$ & 26,58 \\
\hline Muslimani & $28.763-30.238$ & 73,75 & $10.238-10.762$ & 26,25 \\
\hline
\end{tabular}

Izuzetno veliko učešće stradalih žena kod ove dve nacionalne grupe jasno pokazuje težnju da se obe u potpunosti biološki unište. Takođe, broj stradalih žena srpske nacionalnosti, uz njihovo visoko učešće među stradalima ove nacionalnosti, ukazuje da je takođe postojala namera uništenja ove nacionalne grupe, ako ne u potpunosti, ono barem u većem delu. Upoređujući sa civilnim žrtvama ženskog pola tri većinska naroda, odnos u stradanju Jevrejki prema Hrvaticama je 1,13:1, prema Muslimankama je 1,49:1 i prema Srpkinjama je 1:7,79, ali s obzirom na njihovo učešće u stanovništvu, ${ }^{35}$ stvaran odnos u stradanju iznosi 100,78 : $1 \mathrm{u}$ odnosu na Hrvatice, 28,13:1 u odnosu na Muslimanke, kao i 6,66:1 u odnosu na Srpkinje. Upoređujući Jevrejke i Romkinje, kao pripadnice dve manjinske zajednice koje su bile pod udarom rasnih zakona i gotovo u potpunosti uništene, odnos u stradanju je $1,32: 1$, ali s obzirom na njihovu zastupljenost u stanovništvu NDH (1,20:1) stvaran odnos u stradanju žena dva naroda je 1,10:1.

Do sada popisom prikupljeni podaci pružaju mogućnost utvrđivanja odgovornosti za stradanje, odnosno utvrđivanje izvršilaca zločina nad Jevrejima u NDH. Sledeći nemački primer u sprovođenju rasnih zakona, vladajuća elita NDH se opredelila za njihovo uništenje. Ustaše su odgovorne za stradanje između 21.660 i 23.137 osoba, što je 74,66\% stradalih Jevreja. U Evropi zahvaćenoj holokaustom, NDH predstavlja jedini njen deo gde lokalna vlast snosi veću odgovornost za stradanje Jevreja od nacističke Nemačke. Iako su ustašama odali priznanje za napore u uništavanju Jevreja, Nemci ipak nisu bili zadovoljni brzinom „obavljanja posla“, pa su se sami umešali u njegovo sprovođenje. Zajedno sa ustašama sproveli su dve velike akcije sakupljanja Jevreja u avgustu 1942. i maju 1943. godine, ${ }^{36}$ koji su zatim deportovani za logore na istoku, tako da su odgovorni za stradanje između 7.219 i 7.733 osoba što je $24,92 \%$ stradalih Jevreja. Za razliku od njih, Italijani su odgovorni za mali broj stradalih koji se kreće između 122 i 130 osoba $(0,42 \%)$, a koji su se našli u njihovoj zoni odgovornosti. Primetne su razlike u odgovornosti za stradanje Jevreja (vršenju zločina) po pojedinim teritorijama.

${ }^{35}$ Učešće Jevreja u stanovništvu NDH prema tri najbrojnija naroda iznosi 1:89,19 u odnosu na Hrvate, 1:18,88 na Muslimane i 1:51,92 na Srbe.

${ }^{36}$ Opširnije: I. Goldstein, Holokaust..., 424-435, 465-476. 


\begin{tabular}{|c|c|c|c|c|c|c|c|}
\hline $\begin{array}{c}\text { Izvršioci } \\
\text { zločina }\end{array}$ & $\overline{\mathrm{DH}}$ & $\%$ & Nemci & $\%$ & Italijani & $\%$ & Uk \\
\hline Hrvatska & 964 & 61,25 & -6.845 & 8,24 & &, 51 & 16.7 \\
\hline$\%$ & 47,31 & $\pi$ & 88,49 & & 69,8 & & \\
\hline $3 \mathrm{iH}$ & -11.014 & 93,34 & $3-747$ &, 33 & $37-$ & 0,33 & 11.10 \\
\hline$\%$ & 71 & & 9,70 & & 30,16 & 1 & \\
\hline rem & $70-1.159$ & 89,15 & $0-141$ & 10,85 & & & 1.2 \\
\hline$\%$ & & $/ 1$ & & & & & \\
\hline kup & $660-23.137$ & 74,66 & 119-7.733 & 24,92 & 122-130 & 0,42 & $9.000-31.00$ \\
\hline
\end{tabular}

Tako su Nemci najveći deo Jevreja nad kojim su izvršili zločin, 88,49\%, pokupili sa teritorije Hrvatske, dok je njihovo učešće u odgovornosti za stradanje Jevreja na ostalim teritorijama bilo jako malo. Ovo se može tumačiti time što je jevrejska zajednica u Hrvatskoj bila gotovo dvostruko brojnija od zajednice u $\mathrm{BiH}$, a višestruko brojnija od one u Sremu. Ustaše su gotovo podjednak broj zločina izvršili nad Jevrejima Hrvatske i BiH, a znatno manji broj u Sremu, s time što je njihovo delovanje bilo dovoljno za uništenje jevrejske zajednice u $\mathrm{BiH}$ i Sremu. Slabiji učinak ustaša u eliminaciji Jevreja u Hrvatskoj prouzrokovao je nemačko mešanje. Ako posmatramo najveće jevrejske zajednice po gradovima, u Zagrebu je $68,09 \%$ stradalo od ustaša, a $31,91 \%$ od Nemaca, u Sarajevu je 95,92\% stradalo od ustaša, dok je u Osijeku 71,10\% Jevreja stradalo od Nemaca.

Okolnosti stradanja pokazuju da je 96,18\% Jevreja NDH stradalo u logorima (27.892-29.816), još $1,18 \%$ u zatvorima (342-366), dok je 2,64\% izgubilo život (766-818) u pojedinačnim ili masovnim egzekucijama. U logorima stradali Jevreji predstavljaju $16,09 \%$ svih stanovnika NDH koji su izgubili živote u nekom od koncentracionih logora u zemlji ili van nje (između 173.800 i 184.800 osoba). ${ }^{37} \mathrm{Za}$ razliku od stradalih u egzekucijama i zatvorima gde odgovornost za izvršene zločine snose ustaše, odgovornost za stradanje u logorima podeljena je između Nemaca koji su odgovorni za smrt 25,91\% logoraša (između 7.224 i 7.725) i ustaša koje su odgovorni za stradanje 74,09\% logoraša (između 20.667 i 22.083 osoba). Od Jevreja koji su stradali u nemačkim logorima 77,42\% je izgubilo život u Aušvicu (5.589-5.987). Među logorima koje je organizovala NDH po broju stradalih posebno se ističu sistemi logora Gospić i Jasenovac. U svega nekoliko meseci postojanja gospićke grupe logora (Gospić, Jadovno, Pag) u njoj je ubijeno između 1.800 i 2.000 Jevreja, koji čine $12,18 \%$ stradalih. Oni predstavljaju između $6,33 \%$ stradalih u holokaustu, a ujedno čine $8,90 \%$ stradalih Jevreja u logorima koje je organizovala NDH. Mnogo veće razmere stradanja Jevreja zabeležene su u Jasenovačkom logoru.

${ }^{37} \mathrm{U}$ ovaj broj nisu uračunate osobe koje su stradale na prinudnom radu u NDH ili u Nemačkoj, a čiji se položaj ne retko mogao izjednačiti sa položajem zatočenika u konc-logorima. Takođe, u ovaj broj nisu uračunati stradali u logorima za ratne zarobljenike. Opširnije videti: D. Cvetković, Stradanje stanovništva NDH u logorima - numeričko određenje, u: Logori, zatvori i prisilni rad u Hrvatskoj /Jugoslaviji 1941-1945, 1945- 1951. - Zbornik radova (ur. Vladimir Geiger), Zagreb 2010, 41-57. 
Logor Jasenovac, osnovan krajem avgusta 1941, posle zatvaranja gospićke grupe logora preuzeo je njegovu ulogu logora uništenja. Oko broja stradalih u logoru Jasenovac vođena je dugogodišnja polemika. U izvorima i literaturi mogu se pronaći podaci o broju stradalih koji se kreću od 20.000 do preko milion, s time što se najčešće pominje 500.000-600.000, kao i oko 700.000. Broj stradalih Jevreja se uglavnom kreće oko $25.000 .^{38}$ Ovako suprotstavljeni podaci (brojevi) mogu da i kod bolje obaveštenih čitalaca stvore konfuziju u shvatanju nečega što se zvalo koncentracioni logor Jasenovac. Ovaj problem zahteva još dosta rada uz multidisciplinaran, racionalan i neemotivan pristup.

$\mathrm{Na}$ osnovu dostignutih rezultata u reviziji popisa, a prateći do sada iskazan trend u kretanju dobijenih podataka za određene teritorije i određene nacionalnosti, procena je da se broj stradalih u logoru Jasenovac kreće između 122.300 i 130.100 osoba ${ }^{39}$ Veće promene među ubuduće identifikovanim žrtvama u procesu revizije, koje značajno odstupaju od do sada iskazanog trenda u dobijenim podacima, uslovile bi izmenu postojeće procene koja bi dobila druge vrednosti. Stradali u logoru predstavljaju 17,70\% ukupnih ljudskih gubitaka NDH i 24,53\%

${ }^{38}$ Opširnije: J. Mirković, Objavljeni izvori..., 94 i 160. - Nova izložbena postavka SP Jasenovac pruža podatak o 69.842 stradalih u logoru. Iskazani broj predstavlja, prema navodu iz publikacije, rezultat dotadašnjih istraživanja koja su prikazana u „Poimeničnom popisu žrtava KL Jasenovac". Među stradalima je 39.580 Srba, 14.599 Roma, 10.700 Jevreja, 3.462 Hrvata, 747 Muslimana i 754 pripadnika ostalih i neutvrđenih nacionalnosti. (Đorđe Mihovilović, Jelka Smreka, $O$ Poimeničnom popisu žrtava KL Jasenovac, u Spomen područje Jasenovac - katalog, ur. Tea Benčić Rimay, Jasenovac 2006, 218-219), takođe rezultati istraživanja do 31. avgusta 2007. pružaju podatke o 72.193 stradalih u logoru među kojima je 11.723 Jevreja (Jasenovac, žrtva je pojedinac - Poimenični popis žrtava koncetracijskog logora Jasenovac 1941-1945., ur. Tea Benčić Rimay, Jasenovac 2007, 10). Razmatrajući dotadašnja istraživanja o broju stradalih Jevreja u Jasenovcu Ivo i Slavko Godstein došli su do procenjenog broja od 17.000 (I. Goldstein, Holokaust..., 648), što preuzimaju i drugi autori (Nataša Mataušić, Jasenovac 1941.-1945., Logor smrti i radni logor, JasenovacZagreb 2003, 123). Na sajtu Muzeja holokausta iz Vašingtona (USHMM) može se pročitati da je u logoru Jasenovac stradalo između 56.000 i 97.000 osoba. Među stradalima je 45.000-52.000 Srba, 8.000-20.000 hiljada Jevreja, 8.000-15. 000 Roma i 5.000-12.000 Hrvata i Muslimana. Sabiranjem minimalnih i maksimalnih vrednosti dobija se da je u logoru stradalo između 66.000 i 99.000, čime se dovodi u pitanje prethodno iskazan broj stradalih. (poslednje čitanje 22. maja 2009, videti na http//ushmm. org/museum/exhibit/online/jasenovac); Enciklopedija Holokausta pruža podatke o 600.000 ubijenih u Jasenovcu, među kojima je 25.000 Jevreja. Takođe se navodi da je u čitavoj NDH ubijeno 500.000 Srba, iz čega proizilazi da su Srbi stradali isključivo u Jasenovcu. U Enciklopediji se navodi i da je oko milion ljudi stradalo u Jugoslaviji, iz čega proizilazi da je oko $60 \%$ svih žrtava izgubilo život u Jasenovcu. Ako od ukupnih žrtava odbijemo stradale u jedinicama NOVJ - partizanima (nešto manje od 300.000) i ostalim vojnim formacijama, sledi da su svi stradali civili Jugoslavije izgubili život u Jasenovcu. (Encyclopedia..., 175, 280-281, 490). O broju stradalih u logoru Jasenovac videti: I. Graovac D. Cvetković, Ljudski gubici Hrvatske..., 72-75, 97; Jasenovac, zbornik radova, ur. Zdravko Antonić, Banja Luka 2007, 9-415; D. Cvetković, Страдање цивила Независне Државе Хрватске у логору Јасеноваи, Tokovi istorije, 2007, br. 4, 153-168, Srboljub Živanović, Jasenovac, odabrani radovi, članci, intervjui, govori i diskusije, ur. Todor Bjelkić, Beograd-London 2008, 5367; Antun Miletić, NDH - Koncentracioni logor Jasenovac 1941-1945, Beograd 2010.

${ }^{39}$ Do sada je procesom revizije popisa Žrtve rata 1941-1945. utvrđen broj od 84.884 osoba koje su izgubile život u logoru Jasenovac. 
civilnih žrtava NDH. Među svim stanovnicima NDH koji su izgubili život u nekom od koncentracionih logora u NDH ili van nje, stradali u Jasenovcu čine $70,38 \%$, a ujedno predstavljaju i $82,56 \%$ stradalih u logorima koje je organizovala NDH. Takođe, stradali u Jasenovcu predstavljaju između 52,36\% od svih stanovnika Jugoslavije koji su izgubili život u nekom koncentracionom logoru (između 234.300 i 247.700 ). Time on postaje sinonim za stradanje u koncentracionom logoru.

Gledano prema godinama postojanja logora, najveće stradanje od $67,77 \%$ zabeleženo je u 1942. godini kada je život izgubilo između 82.883 i 88.163 osoba. Iako je neuporedivo manje stradanje ostalih godina, po broju se izdvaja prva godina, odnosno prvih četiri meseca postojanja logora, tokom koje je život izgubilo $13,11 \%$ stradalih logoraša. Nacionalna struktura stradalih pokazuje da je među njima 62,60\% Srba (77.000-81.000), 15,06\% Roma (18.000-20.000), 14,66\% Jevreja (18.000-19.000), 4,91\% Hrvata (6.000-6.400), 1,10\% Muslimana (1.300-1.500), 1,66\% ostalih i nepoznatih (2.000-2.200).

Holokaust u Jasenovcu dobija svoj najizrazitiji oblik. U njemu je život izgubilo $61,67 \%$ stradalih Jevreja NDH, zatim $64,11 \%$ Jevreja stradalih u logorima, kao i $86,62 \%$ Jevreja stradalih u logorima koje je organizovala NDH. Jevreji i Romi predstavljaju najveće žrtve logora s obzirom na njihovo učešće u populaciji od 0,59 odnosno $0,48 \%$. Učešće Jevreja među stradalima u logoru je 24 puta a učešće Roma čak 30 puta veće od njihovog učešća u populaciji NDH. Učešće stradalih Srba je više nego dvostruko veće od njihovog učešća u stanovništvu NDH. Sa druge strane učešće stradalih Hrvata i Muslimana je 10,7 odnosno 10 puta manje od njihove zastupljenosti u populaciji. Odnos u stradanju Jevreja prema Hrvatima je 2,98:1, prema Muslimanima 13,33:1 i prema Srbima 1:4,27, ali s obzirom na njihovo učešće $u$ stanovništvu, ${ }^{40}$ stvaran odnos u stradanju iznosi 266,13:1 u odnosu na Hrvate, 251,67:1 u odnosu na Muslimane, kao i 12,16:1 u odnosu na Srbe. U poređenju sa Romima, koji su takođe gotovo u potpunosti uništeni, Jevreji imaju odnos u stradanju od 1:1,03, ali s obzirom na njihovu zastupljenost u stanovništvu NDH $(1,2: 1)$ stvaran odnos u stradanju dva naroda u logoru je 1:1,24.

Ukrštanje godina stradanja sa nacionalnom strukturom stradalih u logoru daje mnogo potpuniju sliku. Tako se može pratiti kakva je percepcija protivnika među pojedinim nacionalnostima od strane režima NDH u određenim periodima rata. To je uslovilo bitne razlike u njihovom stradanju, tako da pojedine nacionalnosti u većem delu stradaju, ili bivaju gotovo u potpunosti uništene, u prvim godinama rata, a neke u poslednjim.

${ }^{40}$ Jevreja u populaciji NDH ima 1:89,19 u odnosu na Hrvate, 1:18,88 na Muslimane i 1:51,92 na Srbe. 
Holokaust u Nezavisnoj Državi Hrvatskoj - numeričko određenje

\begin{tabular}{|c|c|c|c|c|c|c|c|c|c|c|c|}
\hline \begin{tabular}{|c} 
Jaseno- \\
vac
\end{tabular} & 1941 & $\%$ & 1942 & $\%$ & 1943 & $\%$ & 1944 & $\%$ & 1945 & $\%$ & Ukupno \\
\hline Srbi & $\begin{array}{r}7.638- \\
8.015\end{array}$ & 9,91 & $\begin{array}{r}53.969 \\
56.793\end{array}$ & 70,10 & $\begin{array}{r}4.689 \\
4.933\end{array}$ & 6,09 & $\begin{array}{r}7.862- \\
8.270\end{array}$ & 10,21 & $\begin{array}{r}2.834 \\
2.981\end{array}$ & 3,68 & $\begin{array}{r}77.000- \\
81.000\end{array}$ \\
\hline$\%$ & 47,32 & $/ /$ & 64,75 & // & 69,01 & $/ 1$ & 71,74 & $/ /$ & 49,19 & // & 62,60 \\
\hline \begin{tabular}{|l} 
Jevreji \\
\end{tabular} & $\begin{array}{r}3.815 \\
4.026\end{array}$ & 21,19 & $\begin{array}{r}12.067- \\
12.738\end{array}$ & 67,04 & $\begin{array}{r}895- \\
944\end{array}$ & 4,97 & $497-526$ & 2,77 & $\begin{array}{r}725- \\
766 \\
\end{array}$ & 4,03 & $\begin{array}{r}18.000- \\
19.000\end{array}$ \\
\hline$\%$ & 23,70 & // & 14,50 & $/ /$ & 13,18 & $/ /$ & 4,55 & // & 12,61 & // & 14,66 \\
\hline Romi & $\begin{array}{r}3.199 \\
3.527\end{array}$ & 17,70 & $\begin{array}{r}13.475 \\
14.999\end{array}$ & 74,93 & $\begin{array}{r}351- \\
390\end{array}$ & 1,95 & $\begin{array}{c}929- \\
1.032\end{array}$ & 5,16 & $\begin{array}{r}47- \\
52\end{array}$ & 0,26 & $\begin{array}{r}18.000- \\
20.000\end{array}$ \\
\hline$\%$ & 20,33 & $1 /$ & 16,65 & $/ 1 /$ & 5,31 & $/ 1$ & \begin{tabular}{|l|}
8,72 \\
\end{tabular} & $\pi$ & 0,84 & $/ 1$ & 15,06 \\
\hline Hrvati & $820-893$ & 13,81 & $\begin{array}{r}1.744 \\
1.842\end{array}$ & 28,91 & $\begin{array}{r}515- \\
559\end{array}$ & 8,66 & $\begin{array}{r}1.157- \\
1.240\end{array}$ & 19,33 & $\begin{array}{r}1.765- \\
1.866\end{array}$ & 29,28 & $\begin{array}{r}6.000 \\
6.400\end{array}$ \\
\hline$\%$ & 5,17 & // & 2,10 & // & 7,70 & // & 10,65 & // & 30,71 & // & 4,91 \\
\hline \begin{tabular}{|c|} 
Musli- \\
mani
\end{tabular} & $\begin{array}{r}143- \\
165\end{array}$ & 10,99 & $296-341$ & 22,74 & $\begin{array}{r}168 \\
194\end{array}$ & 12,95 & $378-436$ & 29,05 & \begin{tabular}{|r|}
$316-$ \\
364
\end{tabular} & 24,27 & $\begin{array}{r}1.300 \\
1.500\end{array}$ \\
\hline$\%$ & 0,93 & $1 /$ & 0,37 & $1 /$ & 2,60 & $/ /$ & 3,62 & $/ 1$ & 5,75 & $/ /$ & 1,10 \\
\hline \begin{tabular}{|c} 
Ostali \\
i nepo- \\
znati \\
\end{tabular} & $\begin{array}{r}386 \\
454\end{array}$ & 20,0 & $\begin{array}{r}1.334 \\
1.448\end{array}$ & 66,24 & $\begin{array}{r}151- \\
156\end{array}$ & 7,31 & $\begin{array}{r}78- \\
85\end{array}$ & 3,89 & $\begin{array}{r}51- \\
56\end{array}$ & 2,55 & $\begin{array}{r}2.000- \\
2.200\end{array}$ \\
\hline$\%$ & 2,54 & $/ /$ & 1,63 & $/ 1$ & 2,19 & $1 /$ & 0,72 & $1 /$ & 0,90 & $1 /$ & 1,66 \\
\hline Ukupno & $\begin{array}{r}15.997- \\
17.081\end{array}$ & 13,11 & $\begin{array}{r}82.883- \\
88.163\end{array}$ & 67,77 & $\begin{array}{r}6.763- \\
7.179 \\
\end{array}$ & 5,52 & $\begin{array}{r}10.897- \\
11.591\end{array}$ & 8,91 & $\begin{array}{r}5.736- \\
6.086\end{array}$ & 4,68 & $\begin{array}{r}122.300- \\
130.100\end{array}$ \\
\hline
\end{tabular}

S obzirom na prirodu logora, koja proističe iz razloga za njegovo formiranje, primetna je neravnomernost u stradanju među pojedinim nacionalnostima, tako da se jasno izdvajaju dve grupe među stradalima. U prvu i znatno veću grupu spadaju nacionalnosti koje su bile predviđene za uništenje u NDH. Kod njih je najveći deo stradao u prve dve godine postojanja logora. U nju se svrstavaju Romi sa 92,63\% (16.674-18.526), Jevreji sa 88,22\% (15.879-16.761), ostale i neutvrđene nacionalnosti sa $86,24 \%(1.720-1.902)$ i Srbi sa $80,01 \%$ stradalih (61.607-64.808). Kod svih nacionalnosti iz ove grupe više od $66,24 \%$ stradalih je izgubilo život u 1942. godini, dok je od Roma tada stradalo 74,93\%. Drugu, manju grupu sačinjavaju nacionalnosti kod kojih je značajan deo ili pak većina stradala u poslednje dve godine rata, a u nju spadaju Muslimani sa 53,32\% (694$800)$ i Hrvati sa $48,61 \%$ stradalih $(2.922-3.106)$. S obzirom na to da je prve ratne godine logor postojao svega četiri meseca, a da je broj stradalih Jevreja druge godine 3,16 puta veći nego prve, godišnja stopa stradanja je gotovo izjednačena u prve dve godine postojanja logora. Broj stradalih Jevreja 1943. godine je 13,49 puta manji nego prethodne godine.

Iako je najveći deo stradalih kod svih nacionalnosti izuzev Muslimana i Hrvata (približno jednako stradanje druge i poslednje godine rata) izgubio život tokom 1942. godine, njihovo učešće među stradalima nije jednako svake godine. Kod Jevreja je najveće učešće među stradalima zabeleženo tokom prve godine postojanja logora, kada ono iznosi $23,70 \%$, što je znatno više od njihovog ukupnog učešća među stradalima logora. U narednom periodu učešće Jevreja među stradalima u logoru kretalo se u 1942. godini u okviru ukupnog proseka $(14,50 \%)$, 
nešto ispod proseka za narednu i poslednju godinu rata $(13,18$ odnosno 12,61), sa izrazitim padom u 1944. godini kada učestvuju sa 4,55\%. Poput Jevreja i kod Roma je najveće učešće među stradalima zabeleženo tokom prve godine postojanja logora kada ono iznosi $20,30 \%$, što je kod ove nacionalne grupe znatno više od njenog ukupnog učešća među stradalima logora. ${ }^{41}$ Sa druge strane, kod Hrvata i Muslimana je tek poslednje godine postojanja logora (godina sa najmanjim brojem stradalih) registrovano značajnije učešće među stradalima од 30,71\% odnosno $5,75 \%$, što je više nego 5 puta iznad procentualnog učešća obe nacionalne grupe među stradalima logora. Kod Srba, daleko najbrojnije grupe među stradalima, primetno je variranje u učešću među stradalima u pojedinim periodima postojanja logora. Najveće učešće među stradalima zabeleženo je tokom 1943. i naročito 1944. godine kada iznosi $69,01 \%$ odnosno $71,74 \%$, što je znatno više od njihove prosečne zastupljenosti među stradalima, mada je i 1942. godine njihovo stradanje $(64,75 \%)$ bilo nešto iznad nacionalnog proseka. Najmanje učešće je registrovano tokom prve (zbog značajnog učešća Jevreja i Roma) i poslednje godine rata (zbog povećanog učešća Hrvata i Muslimana) kada iznosi $47,32 \%$ odnosno $49,11 \%$, što je znatno ispod njihovog prosečnog učešća među stradalima.

U naporima da „reše jevrejsko pitanje“ u NDH, ustaše su u logor Jasenovac dovodili Jevreje iz svih delova države. Analiza teritorijalne pripadnosti žrtava pokazuje da Jevreji iz različitih oblasti, s obzirom na brojnost jevrejske populacije nastanjene na njima, nisu podjednako stradali u logoru. Polovina, tačnije $51,75 \%$, stradalih potiče iz BiH (9.315-9.833), iako su oni činili 33,80\% jevrejske zajednice u NDH, dok je relativno malo učešće Jevreja iz Hrvatske, od $38,17 \%$, (6.871-7.252), s obzirom na to da je na njenoj teritoriji živelo $61,97 \%$ Jevreja NDH. Učešće među stradalima u logoru od 6,08\% Jevreja iz Srema (1.094-1.155) veće je od njihove zastupljenosti među Jevrejima NDH (4,23\%). Među stradalima je i $4 \%$ Jevreja iz ostalih delova Jugoslavije van NDH, a koji su uglavnom živeli na njenoj teritoriji (720-760). Od stradalih Jevreja BiH 83,61\% je izgubilo život u Jasenovcu, a slično je i sa Jevrejima iz Srema kojih je tu stradalo $89,96 \%$. Sa druge strane u ovom logoru život je izgubilo $40,82 \%$ stradalih Jevreja iz Hrvatske. Ukrštanje teritorijalne pripadnosti žrtava sa godinama stradanja u logoru pokazuje da Jevreji sa različitih teritorija nisu podjednako stradali u pojedinim periodima rata.

${ }^{41}$ Za razliku od Jevreja, kod Roma je i tokom 1942. godine registrovano učešće među stradalima od $16,65 \%$, koje je veće od njihovog prosečnog učešća među stradalima, da bi u narednim godinama usledio pad u učešću, tako da poslednje godine postojanja logora ono iznosi ispod jednog procenta $(0,84 \%)$. 


\begin{tabular}{|c|r|r|r|r|r|r|r|r|r|r|r|}
\hline $\begin{array}{c}\text { Jevreji } \\
\text { u Jasenovcu }\end{array}$ & \multicolumn{1}{|c|}{$\begin{array}{l}1941 \\
\text { Hrvatska }\end{array}$} & $\begin{array}{r}1.903-27,69 \\
2008\end{array}$ & $\begin{array}{r}3.689-53,69 \\
3.894\end{array}$ & $438-462$ & 6,37 & $330-$ & 4,81 & $511-540$ & 7,44 & $6.871-$ \\
7.252 \\
\hline$\%$
\end{tabular}

Iako je druga godina postojanja logora bila najpogubnija po Jevreje, primetne su razlike u vremenu stradanja među pojedinim delovima države iz kojih su poticali Jevreji. Tokom 1942. godine u logoru je život izgubilo 53,69\% Jevreja iz Hrvatske, 76,64\% Jevreja Bosne i Hercegovine i 86,81\% Jevreja iz Srema. Poslednje godine postojanja logora stradalo je 7,44\% Jevreja iz Hrvatske, dok je u tom periodu izgubilo život 1,67\% Jevreja BiH i 1,51\% Jevreja iz Srema. Indikativno je da je $42,50 \%$ Jevreja rođenih van teritorije NDH, a koji su se iz porodičnih, poslovnih ili drugih razloga nalazili na njenoj teritoriji, stradalo u prva četiri meseca postojanja logora. Iako u ukupnom broju stradalih sunarodnika u logoru učestvuju sa $38,17 \%$, Jevreji iz Hrvatske imaju najveće učešće među stradalima tokom svih godina postojanja logora, počev od prve sa $49,88 \%$ do poslednje sa 70,49\%, izuzev u 1942. godini kada njihovo učešće iznosi 30,57\%. Kao najbrojniji među stradalim sunarodnicima u Jasenovcu, Jevreji iz BiH natpolovično učešće imaju samo u 1942. godini, kada ono iznosi 59,16\%, a značajnije učešće, od $40,82 \%$, zabeleženo je i u prvoj godini postojanja logora. Jevreji iz Srema zapaženije učešće među stradalima od 7,87\% imaju u drugoj, a Jevreji rođeni van $\mathrm{NDH}$ u prvoj godini postojanja logora sa $8,02 \%$. Iako je godišnja stopa smrtnosti u logoru prve i druge godine rata bila gotovo izjednačena, ona nije ista na svim teritorijama. Kod Jevreja iz Srema i BiH uvećana je 6,52 odnosno 1,53 puta, dok je kod Jevreja iz Hrvatske i rođenih van teritorije NDH smanjena 1,55 odnosno 3,18 puta. Broj stradalih 1943. godine je u odnosu na prethodnu godinu smanjen kod Jevreja iz Hrvatske 8,43 puta, iz BiH 19,45 puta, iz Srema 24,38 puta i kod Jevreja rođenih van teritorije NDH 5,63 puta.

Analiza polne strukture pokazuje da su u logoru gubili živote pripadnici oba pola, ali da gubitak nije bilo ujednačen tako da žene čine $42,87 \%$ stradalih, što je između 52.507 i 55.705 osoba. Takođe, ni učešće polova među stradalima u okviru pojedinih nacionalnosti nije isto. 


\begin{tabular}{|l|r|r|r|c|}
\hline \multicolumn{1}{|c|}{ Jasenovac } & \multicolumn{1}{c|}{ Muškarci } & \multicolumn{1}{c|}{$\%$} & \multicolumn{1}{c|}{ Žene } & $\%$ \\
\hline Srbi & $44.737-47.061$ & 58,10 & $32.263-33.939$ & 41,90 \\
\hline Romi & $9.461-10.512$ & 52,56 & $8.539-9.488$ & 47,44 \\
\hline Jevreji & $9.483-10.177$ & 53,13 & $8.517-8.823$ & 46,86 \\
\hline Hrvati & $3.978-4.243$ & 66,30 & $2.022-2.157$ & 33,70 \\
\hline Muslimani & $1.002-1.156$ & 77,04 & $298-344$ & 22,96 \\
\hline Ostali i nepoznati & $1.132-1.246$ & 56,62 & $868-954$ & 43,38 \\
\hline Ukupno & $69.793-74.395$ & 57,13 & $52.507-55.705$ & 42,87 \\
\hline
\end{tabular}

Najveće učešće stradalih žena od 47,44 odnosno 46,86\% zabeleženo je kod Roma i Jevreja, zatim kod grupe ostalih i nepoznatih nacionalnosti sa $43,38 \%$ i ona su iznad prosečnog učešća žena među stradalima, dok im je jako blizu i učešće Srpkinja od 41,90\%. Najniža zastupljenost žena među stradalima u logoru zabeležena je kod Muslimana sa 22,96\%, dok je nešto veća kod Hrvata, $33,70 \%$. Iako je na nivou NDH kod Jevreja zabeleženo nešto veće učešće stradalih žena $(52,04 \%)$ nego muškaraca, to nije slučaj i sa stradalim ženama u logoru Jasenovac, pošto je deo Jevrejki deportovan za nemačke koncentracione logore ili je izgubio život u nekom drugom logoru NDH. Među stradalim ženama Jevrejke čine $16,02 \%$ što je nešto više od učešća njihove nacionalne grupe u ukupnom stradanju u logoru. U Jasenovcu stradale Jevrejke predstavljaju između $55,53 \%$ sunarodnica iz NDH stradalih u holokaustu. U logoru je odnos u stradanju Jevrejki prema Hrvaticama 4,15:1, prema Muslimankama 27,01:1, dok je prema Srpkinjama 1:3,82, ali s obzirom na njihovo učešće u stanovništvu (1:89,19 u odnosu na Hrvate, 1:18,88 na Muslimane i 1:51,92 u odnosu na Srbe), stvaran odnos u stradanju iznosi 370,14:1 u odnosu na Hrvatice, 509,95:1 u odnosu na Muslimanke, kao i 13,59:1 u odnosu na Srpkinje. U poređenju sa Romima, koji su takođe gotovo u potpunosti uništeni, Jevreji imaju odnos u stradanju žena od $1: 1,04$, ali s obzirom na njihovu zastupljenost u stanovništvu NDH $(1,20: 1)$ stvaran odnos u stradanju žena dva naroda u logoru je 1:1,25.

Utvrđivanje socijalno-ekonomske strukture stradalih značajno je zbog što potpunije rekonstrukcije nestalih zajednica, posebno jevrejske, kao i zbog utvrđivanja materijalne i nematerijalne štete koja je nastala usled neostvarenih ili prekinutih karijera, kao i usporavanja modernizacijskih tokova koje je nestanak Jevreja prouzrokovao. Socijalno-ekonomska struktura može se sagledati preko profesionalne strukture stradalih. Profesionalna struktura stradalih u logoru je poznata u $82,38 \%$ slučajeva (100.751-107.176), dok se za preostalih $17,62 \%$ i dalje traga. Kod Jevreja stradalih u logoru nepoznatih profesija je $29,71 \%$, što je znatno lošije u odnosu na ostale nacionalnosti (izuzev Roma). Među stradalima sa poznatim zanimanjem (na osnovu kojih je izvršen proračun za sve stradale) uočljive su dve grupe: oni koji su ostvarivali prihode (radnoaktivni) i kojih je 48,43\% (59.23063.007) i oni koji nisu ostvarivali prihode i kojih je 51,57\% (63.070-67.093). Među njima izdržavana lica čine 45,58\% (55.744-59.300), a đaci i studenti $5,99 \%$ od ukupnog broja stradalih (7.326-7.793). 
Profesionalna struktura stradalih u logoru nije ista kod svih nacionalnosti. Najveće učešće neproduktivnog dela stanovništva registrovano je kod Jevreja, kod kojih ono predstavlja 53,89\% stradalih (9.698-10.237). Slična zastupljenost je zabeležena kod Srba gde iznosi $51,77 \%$, dok je znatno manja kod Hrvata $(30,96 \%)$ i Muslimana (25,75\%). Izdržavana lica (žene, deca i starije osobe) među stradalima čine 41,80\% kod Jevreja (7.524-7.942), nešto više kod Srba $46,53 \%$ (35.828-37.689), dok ih je 24,67\% kod Hrvata (1.480-1.579) i 19,16\% kod Muslimana (249-287). Đaci i studenti čine 12,08\% stradalih Jevreja (2.1742.295), 5,24\% stradalih Srba (4.035-4.244), 6,28\% Hrvata (377-402) i 6,59\% stradalih Muslimana (86-99). Među svim u logoru stradalim đacima i studentima Jevreja je $29,56 \%$, što je dvostruko više od njihove procentualne zastupljenosti među stradalima u logoru.

Uništavanje dva (odnosno tri) naroda u totalu prouzrokovalo je da radnoaktivno (produktivno) stanovništvo čini $46,11 \%$ u logoru stradalih Jevreja (8.300-8.761) i 48,23\% stradalih Srba (37.137-39.066). Sa druge strane, produktivan deo stanovništva čini $69,04 \%$ u logoru stradalih Hrvata (4.142-4.419) i $74,25 \%$ stradalih Muslimana (969-1.114). Razvrstavanje profesionalne strukture prema grupama zanimanja u okviru pojedinih nacionalnosti daje potpuniju sliku.

\begin{tabular}{|l|l|l|r|r|}
\hline Jasenovac & \multicolumn{1}{l|}{ Srbi } & Hrvati & Jevreji & Muslimani \\
\hline Poljoprivrednici & $29.175-30.690$ & $1.224-1.305$ & $80-84$ & $336-386$ \\
\hline$\%$ & 78,56 & 29,54 & 0,96 & 34,68 \\
\hline Privrednici & $2.002-2.106$ & $796-849$ & $4.148-4.378$ & $180-207$ \\
\hline$\%$ & 5,39 & 19,21 & 49,97 & 18,55 \\
\hline Radnici & $3.365-3.539$ & $1.002-1.069$ & $1.025-1.082$ & $286-329$ \\
\hline$\%$ & 9,06 & 24,20 & 12,35 & 29,52 \\
\hline Službenici i stručnjaci & $1.433-1.508$ & $832-888$ & $2.134-2.252$ & $102-117$ \\
\hline$\%$ & 3,86 & 20,09 & 25,71 & 10,48 \\
\hline Slobodne profesije & $163-172$ & $72-77$ & $422-445$ & $13-14$ \\
\hline$\%$ & 0,44 & 1,75 & 5,08 & 1,29 \\
\hline Lica sa ličnim prihodima & $182-191$ & $41-43$ & $215-227$ & 5 \\
\hline$\%$ & 0,49 & 0,98 & 2,59 & 0,48 \\
\hline Vojska, žandarmerija i policija & $182-191$ & $48-51$ & $7-8$ & $9-11$ \\
\hline$\%$ & 0,49 & 1,16 & 0,09 & 0,97 \\
\hline Ostala zanimanja & $542-570$ & $106-113$ & $222-234$ & $28-32$ \\
\hline$\%$ & 1,46 & 2,56 & 2,67 & 2,90 \\
\hline Nezaposleni & $93-98$ & $22-23$ & $48-51$ & $9-11$ \\
\hline$\%$ & 0,25 & 0,52 & 0,58 & 0,97 \\
\hline
\end{tabular}

Pošto su u logoru Jasenovac uništavani u potpunosti kao nacije, profesionalna struktura stradalih Jevreja i Srba približno je jednaka njihovoj profesionalnoj strukturi u predratnoj populaciji. Sa druge strane, profesionalna struktura u logoru stradalih Hrvata i Muslimana, koja nije u skladu sa njihovom strukturom u predratnoj populaciji ovih naroda, uz relativno malo ušeće neproduktivnog dela stanovništva među stradalima, ukazuje na to da su u logoru stradali, bilo kao pripadnici, odnosno simpatizeri komunističkog pokreta ili pak kao simpatizeri stra- 
naka građansko-liberalne, a samim time i antifašističke orijentacije koje su se opirale režimu. Poređenje profesionalne strukture stradalih Jevreja sa adekvatnim strukturama ostalih nacionalnost pokazuje da oni predstavljaju $58,13 \%$ stradalih privrednika, 47,33\% službenika i stručnjaka i $62,93 \%$ pripadnika slobodnih profesija, uz pomenuto veliko učešće među stradalim đacima i studentima $(29,56 \%)$. Ako se uzme u obzir činjenica da su oni predstavljali samo $0,59 \%$ populacije, u kojoj je natpolovični deo stanovništva bio nepismen, ${ }^{42}$ jasno je koliko je velik gubitak intelektualnog i modernizacijskog potencijala ne samo jevrejske zajednice već i društva posleratne Jugoslavije.

Logor Jasenovac je imao ključnu ulogu u sprovođenju holokausta u NDH. U njemu je život izgubilo 61,67\% stradalih Jevreja NDH, zatim 64,11\% Jevreja stradalih u logorima, kao i $86,62 \%$ Jevreja stradalih u logorima koje je organizovala NDH. U njemu je izgubilo život 55,53\% Jevrejki stradalih u holokaustu. Posebno je bio poguban po Jevreje BiH i Srema, jer je u njemu život okončalo 83,61 odnosno $89,96 \%$ od svih stradalih u holokaust sa ovih teritorija. Učešće Jevreja među stradalima u logoru je 24 puta veće od njihovog učešća u populaciji NDH. Njihovo stradanje se jedino može uporediti sa stradanjem Roma, kojih je u logoru izgubilo život $76,00 \%$ i čije je učešće među stradalima 30 puta veće od njihove zastupljenosti u populaciji. Iako su daleko najbrojniji među žrtvama u Jasenovcu, sa učešćem među stradalima dvostruko većim od njihovog učešća u populaciji, Srbi su u logoru izgubili između 22,44 i 23,80\% stradalih civila iz NDH, tako da stradanje u logoru predstavlja samo deo zločina učinjenog nad ovim narodom. U Jasenovcu je izgubilo život oko 3,5\% stradalih civila Muslimana i između 11,48 i 12,16\% stradalih civila Hrvata, a ove nacionalnosti su u logoru imale učešće među stradalima 11 odnosno 10 puta manje od njihove zastupljenosti u stanovništvu NDH.

Od svog osnivanja u aprilu 1941. godine NDH se po rasnim zakonima koje je donosila i praktičnom delovanju eksponirala kao izrazito antisemitska. Sledeći nemački primer, a povremeno koristeći njihovu pomoć, potrudila se da sprovede „konačno rešenje jevrejskog pitanja“, izdvojivši se u mnogo čemu kao jedinstvena na ovom prostoru, ali i u Evropi. Na osnovu podataka delimično revidiranog popisa Žrtve rata 1941-1945. procenjuje se da je na teritoriji NDH u holokaustu stradalo između 29.000 i 31.000 Jevreja civila (ne računajući stradanje više od hiljadu emigranata koji su se zatekli na toj teritoriji) što je oko 78,95\% od zajednice koja je živela u NDH. Gubicima jevrejske populacije treba pridružiti

${ }^{42}$ Delimičnu sliku pismenosti stanovništva NDH možemo sagledati preko pokazatelja o pismenosti stanovništva u banovinama iz popisa 1931. godine, uz uvažavanje činjenice da su se u okviru NDH našli samo veći ili manji delovi pojedinih banovina. Tako je pismenost stanovništva starijeg od 10 godina bila u Savskoj banovini 72,3\%, Vrbaskoj 27,4\%, Drinskoj 37,9\%, Zetskoj $34,0 \%$, Primorskoj 42,6\%, Dunavskoj 71,1\%. (Љубодраг Димић, Културна политика у Краљевини Југославији 1918-1941, Београд 1996, књ. I, 56). 
oko 700 Jevreja koji su stradali kao pripadnici Vojske Kraljevine Jugoslavije ili u partizanskom pokretu koje je predvodila Komunistička partija Jugoslavije. Sa učešćem od svega $0,59 \%$ u populaciji NDH oni predstavljaju 5,83\% stradalih. Među stradalim civilima učešće Jevreja je 10 puta veće od njihovog učešća u populaciji NDH. Oni predstavljaju jedinu nacionalnu grupu u NDH kod koje je stradalo više žena nego muškaraca (52,04\%). Od stradalih u holokaustu 79,67\% je izgubio život u prve dve godine rata (23.109-24.692). Specifičnost ,rešavanja jevrejskog pitanja" u NDH sastoji se u tome što je to jedino područje u Evropi u kome je „domaća“ vlast ubila više Jevreja nego što su ih ubili Nemci. U 74,66\% slučajeva odgovornost za stradanje snose ustaše (21.660 i 23.137), dok je za $24,92 \%$ stradalih odgovornost na Nemcima (7.219 i 7.733). Okolnosti stradanja pokazuju da je 96,18\% Jevreja NDH stradalo u logorima (27.892-29.816), još $1,18 \%$ u zatvorima (342-366), dok je 2,64\% izgubilo život (766-818) u pojedinačnim ili masovnim ekzekucijama. Među logorima se posebno izdvaja Jasenovac u kome je holokaust u NDH dosegao vrhunac, gde Jevreji (uz Rome), s obzirom na zastupljenost u populaciji, predstavljaju najveće žrtve. U Jasenovcu je stradalo između 18.000 i 19.000 Jevreja NDH što je oko 62\% svih stradalih, a ujedno i polovina njihove predratne populacije u NDH. U njemu je okončalo život oko $84 \%$ stradalih Jevreja BiH, 90\% stradalih Jevreja Srema i 41\% stradalih Jevreja Hrvatske. 
Dragan Cvetković

\section{HOLOCAUST IN INDEPENDENT STATE OF CROATIA}

\section{Summary}

Since the creation of the Independetn State of Croatia (NDH) on 10th of April 1941, it developed racial laws and pracitice which may be marked as purely antisemitic. Following the German example, a occasionally with their help, NDH conducted "the final solution“ of the Jewish "question“. According to some unique ways of handling this problem, it can be said that it was unique in this part of Europe. According to the partly revised document tittled The Vicitms of the wear 1941-1945, it could be estimated that on the territory od NDH, between 29.000 and 31.000 Jews were exterminated. Those figures not count several of thousands of the Jews which were temporarely stationed on NDH soil. Mentioned figures, showed that around $79 \%$ of the pre-war Jewish community that lived in the territory of Yugoslavia, that became NDH was exterminated. To the losses of the Jewish community aditional figure of 700 shoould be added which includes those who were acitive in the Royal Yugolsav Army or as resiters inside Communist Partisan movement. With only $0,59 \%$ part of the population, they represent $5,83 \%$ of the total losses. Which is ten times bigger than the Jewish part of the population. It is worth adding that the Jewish population was the only one which have more female than male losses $(52,04 \%)$. nearly $80 \%$ of the killed Jews was in the first two years of the war, meaninig 1941 (23.109) and 1942 (24.692). Special feature of the solving of the Jewish question inside of the NDH, is that this is the only area in the Europe, where the local authorities exterminated more Jews than the Germans. This scale is $75 \%: 25 \%$ for the responiblity of the local authorities. Of the complete number $96,18 \%$ of the Jews were killed in the concnetration camps, $2,64 \%$ in mass exectuions, and $1,18 \%$ in th prisons. The most notorious of whole death-camps was one at Jasenovac. Between 18.000 and 19.000 Jews were killed there, which is around $62 \%$ of the whole Jewish losses ane nearly half of the pre-war Jewish population in territory of NDH during the Second World War. 